\title{
TLR6 wt Allele
}

National Cancer Institute

\section{Source}

National Cancer Institute. TLR6 wt Allele. NCI Thesaurus. Code C52245.

Human TLR6 wild-type allele is located within $4 \mathrm{p} 14$ and is approximately $3 \mathrm{~kb}$ in length.

This allele, which encodes toll-like receptor 6 protein, is involved in both pathogen

recognition and innate immunity activation. 